\title{
Effect of Replacing Bone Ash with Fresh Water Snail (Pila ampullacea) Shell Ash on the Performance of Weaned Rabbits
}

\author{
F. B. P. Abang ${ }^{a^{*}}$, S. S. Emmanuel ${ }^{b}$ and S. Attah ${ }^{c}$ \\ ${ }^{a}$ Department of Animal Science, Faculty of Agriculture, University of Calabar, Calabar, Nigeria. \\ ${ }^{b}$ Department of Animal Production, Federal University of Agriculture, Makurdi, Benue State, Nigeria. \\ ${ }^{c}$ Department of Agriculture and Natural Resources, Gbajimba, Guma, Benue State. Nigeria.
}

Authors' contributions

This work was carried out in collaboration among all authors. Author FBPA designed the study, performed the statistical analysis, wrote the protocol, and wrote the first draft of the manuscript.

Authors SSE and SA managed the analyses of the study. Author SSE managed the literature searches. All authors read and approved the final manuscript.

Article Information

DOI: $10.9734 / A R R B / 2021 /$ v36i1130456 Editor(s):

(1) Dr. Bechan Sharma, University of Allahabad, India.

Reviewers:

(1) Snehangsu Sinha, College of Veterinary Science, India. (2) Umaporn Pastsart, Prince of Songkla University, Thailand. Complete Peer review History, details of the editor(s), Reviewers and additional Reviewers are available here: https://www.sdiarticle5.com/review-history/74380

Original Research Article

Received 15 July 2021 Accepted 25 September 2021 Published 09 December 2021

\begin{abstract}
Twenty five weaned male rabbits of mixed breeds were used to investigate the effect of replacing bone ash with fresh water snail shell ash on the performance of weaned rabbits. The experiment was conducted at the Teaching and Research Farm, University of Agriculture, Makurdi, Benue State, Nigeria for a period of 12 weeks. The rabbits were randomly assigned to the five dietary treatments and replicated five times giving a total of one rabbit per replicate in a completely randomized design (CRD). Rabbits were raised intensively in hutches of about $4 \mathrm{ft} \times 4 \mathrm{ft}$. Five experimental diets tagged $T_{1}$ to $T_{5}$ were formulated such that fresh water snail shell ash replaced bone ash at $0 \%, 25 \%, 50 \%, 75 \%$ and $100 \%$. Feed and water were served ad libitum. Bio sanitary and bio security measures were strictly adhered. The study showed that the growth parameters were not affected $(P=.05)$ by the dietary treatments. This study had shown that fresh water snail shell ash can serve as a substitute for bone ash in weaned rabbits diet up to $100 \%$ without compromising their performances.
\end{abstract}


Keywords: Rabbit; fresh water snail shell ash; bone ash; performance indices.

\section{INTRODUCTION}

Animal protein consumption in Nigeria is about $7.4 \mathrm{~g}$ per capita/day [1], instead of the $28 \mathrm{~g}$ per person per day recommended by the [2]. The wide gap between the estimated protein requirement and the actual protein consumed is as a result of poor nutritional situation in Nigeria [3]. This indicates the need to intensify livestock production. Viable options need to be explored and evaluated in order to achieve this objective [4-6]. The use of livestock species that are yet to play a major role in animal production is among such alternative. Rabbit production has the potentials of alleviating animal protein deficiency in Nigeria [7].

The rabbit has great potentials and good attributes such as; fast growth rate, high efficiency in converting forage to meat, short generation interval, high prolificacy, relatively low cost of production, and high nutritional quality of rabbit meat which includes; low fat, sodium and cholesterol levels. Rabbit meat contains about $20.8 \%$ of protein and its consumption is bereft of cultural and religious biases [8].

There is an urgent need to explore the potentials of non-conventional calcium sources that do not compete with human for food. One of such alternative feedstuff that is cheap, locally available, less competitive with humans and livestock is the fresh water snail shells. Fresh water snail in river Benue and its tributaries has been studied by [9]. The abundance of fresh water snails is as a result of availability of food, shelter and oviposition sites along the said river water body. One of the most successful methods of catching is hand picking done as a community effort on regular basis. Snail shell is a mineral ingredient that contains about $98 \%$ of calcium carbonate [10]. It is therefore a biological source of calcium that can be used in animal feeding. Investigations have been done on the use of many sources of calcium such as gypsum, limestone and oyster shell in layers and broilers diets [11]' but there is a dearth information on the use of snail shells especially fresh water snail shells in animal feeds.

\section{MATERIALS AND METHODS}

\subsection{Experimental Site}

The experiment was conducted in the rabbitry unit at the Teaching and Research Farm, College of Animal Science University of Agriculture Makurdi Benue State. Benue State lies within the lower River Benue trough in the middle belt region of Nigeria. Its geographic coordinates are longitude $7^{\circ} 47^{\prime}$ and $10^{\circ} 0^{\prime}$ East. Latitude $6^{\circ} 25^{\prime}$ and $8^{\circ} 8^{\prime}$ North [12].

\subsection{Source of Bone Ash}

Bone ash was bought at God 4 us livestock consult, beside SRS junction, new bridge road, north bank Makurdi.

\subsection{Sources and Collection of Freshwater Snail Shells}

Fresh water snails are in abundance in River Benue and its tributaries. The test ingredient was sourced locally at Gbajimba and lyeh in Guma Local Government Area and Makurdi metropolis, the flesh is usually removed and the shells are thrown away by the consumers.

\subsection{Processing of Fresh Water Snail Shell}

Fresh water snail shell were collected between the months of February and March. The shells were thoroughly washed with water, dried and burnt at the temperature of about $60^{\circ} \mathrm{C}$ for about 1 hour until they became whitish in appearance; they were then crushed into fine powder as shell ash and used in the diet. The mineral composition of the shell was analyzed by the procedure of Association of Official Analytical Chemists (AOAC) [13].

Table 1. Composition of fresh water snail (pila ampullacea) shell ash and bone ash

\begin{tabular}{ll}
\hline Minerals & $\begin{array}{l}\text { (\%composition) } \\
\text { Pasa }\end{array}$ \\
\hline Ash & 92.45 \\
Calcium & 41.60 \\
Phosphorus & 0.01 \\
Pasa = Pila & \\
ampullacea shell & \\
ash & \\
\hline
\end{tabular}

\subsection{Experimental Design}

A Completely Randomized Design (CRD) was used for this experiment. A total of twenty five weaned male rabbits of mixed breeds at five weeks of age with an initial average weight of 
about 664.00 - $667.00 \mathrm{~g}$ were obtained from Dagwom Farm, National Veterinary Research Institute (NVRI) Vom, Jos Plateau State for the research. The rabbits were allowed for a preliminary feeding period of seven days to enable them acclimatize after which they were randomly assigned to five dietary treatments designated as $T_{1}$ to $T_{5}$. Each of the dietary treatments had five rabbits with each rabbit serving as a replicate.

\subsection{Housing and Management Experimental Animals}

The rabbits were housed individually in the hutches and labeled according to the treatment and replicate assigned to them. The dimension of the hutches was $40 \mathrm{~cm} \times 30 \mathrm{~cm} \times 30 \mathrm{~cm}$, (this was to enable it accommodate the feeders and drinkers). The initial weight of each rabbit was taken before assigning them to one of the five dietary treatments. Prophylactic medication was given against any infection before the commencement of the experiment. Each rabbit was observed daily to ensure good health. A known quantity of diet that will ensure the birds feed ad-libitum was served daily to each replicate, left over feed was weighed daily and quantity consumed was determined by the difference. Fresh clean water was also provided every morning. The experiment lasted for 12 weeks.

\subsection{Experimental Diets}

Five experimental diets were formulated tagged $\mathrm{T}_{1}$ to $\mathrm{T}$. $\mathrm{T}_{1}$ served as a control diet. Fresh water snail shell ash replaced bone ash at $0 \%, 25 \%$, $50 \%, 75 \%$ and $100 \%$ respectively. $\mathrm{T}_{1}$ containing $100 \%$ bone ash while $T_{5}$ contained $100 \%$ fresh water snail shell ash. These were mixed with other ingredients as presented in Table 2 below;

\subsection{Performance Parameters}

The parameters evaluated during the trial include; Initial weight (g), Final body weight gain (g), Average daily feed intake (g), Average weekly weight gain (g), Feed efficiency and Protein efficiency ratio.

\subsection{Average Daily Feed Intake (ADFI) (g)}

The rabbits in each treatment were fed weighed quantity of their group diets daily, feed intake was determined by obtaining the differences between the quantity of feed offered and the left over. Average daily feed intake was determined by dividing the total feed intake of the rabbits by the number of the experimental day

$$
\text { ADFI }=\frac{\text { Total feed intake }(\mathrm{g})}{\text { No of days }}
$$

\subsection{Average Daily Weight Gain (ADWG) (g)}

The initial weight of the rabbits was recorded and they were then weighed on daily basis, therefore, the average daily body weight gain was determined using the formula below:

$$
\mathrm{ADWG}=\frac{\text { Final weight }- \text { Initial weight }(\mathrm{g})}{\text { No of days }}
$$

\subsection{Feed Efficiency (FE)}

This was determined by dividing feed intake by the weight gain

$$
\mathrm{FE}=\frac{\text { Feed intake }(\mathrm{g})}{\text { Weight gained }(\mathrm{g})}
$$

\subsection{Final Body Weight (g)}

The final body weight of the rabbits was determined by weighing the rabbits at the end of the experiment, it was recorded in grams (g).

\subsection{Protein Efficiency Ratio (PER)}

The weight gain per unit of protein consumed was calculated using the formula below:

$$
\text { PER }=\frac{\text { Weight gained }(\mathrm{g})}{\text { Gram of protein taken }}
$$

\subsection{Statistical Analysis}

The data collected were subjected to one way Analysis of Variance (ANOVA) using Minitab statistical software version 16 [14]. The separation of means was effected using Duncan's Multiple Range Test (DMRT) as outline by [15].

\section{RESULTS AND DISCUSSION}

The result of the proximate analysis of fresh water snail shell ash is presented in Table 1. It was observed that fresh water snail shell ash 
contained high percentages of ash $(92.45 \%)$ and calcium $(41.60 \%)$ but has negligible amount of phosphorus $(0.01 \%)$ when compared to bone ash. The result showed that fresh water snail shell ash is a potential source of calcium in livestock feed.

The nutrient composition of the five experimental diets is shown in Table 2. The findings revealed that the proximate fractions were not different from each other significantly. The diets were observed to have met the nutritional requirements for weaned rabbits across treatments [16].

The result of average daily feed intake was not significantly $(P>0.05)$ affected by the dietary treatments. The study recorded daily feed intake values of $84.95-90.32 \mathrm{~g}$, which were generally within the concentrate feed intake ranges of 61.08 to $133.90 \mathrm{~g}$ earlier reported for rabbits [17]. The high dietary inclusion levels of fresh water snail shell ash did not affect feed intake.

The average final weight recorded in this study ranged from 2163.40 to $2237.00 \mathrm{~g}$ and were not significantly $(P>0.05)$ affected by the dietary treatments. The result indicated that fresh water snail shell ash did not influence the final weight of the rabbits. This was in line with the findings of [18] who asserted that oyster shell and gypsum are sources of calcium which aids metabolic activities and not principal nutrient for growth in broiler chickens.

Table 2. Composition of experimental diets with fresh water Snail (Pila ampullacea) shell ash as a replacement for bone ash (\%)

\begin{tabular}{llllll}
\hline Feedstuff & \multicolumn{4}{l}{ Experimental Diets } \\
\hline & $\mathbf{( 0 \% P a s a )}$ & $\mathbf{( 2 5 \% P a s a )}$ & $\mathbf{( 5 0 \% P a s a )}$ & $\mathbf{( 7 5 \% P a s a )}$ & $\mathbf{( 1 0 0 \% P a s a )}$ \\
\hline Maize & 30.00 & 30.00 & 30.00 & 30.00 & 30.00 \\
Full fat soybean & 20.00 & 20.00 & 20.00 & 20.00 & 20.00 \\
Groundnut cake & 12.00 & 12.00 & 12.00 & 12.00 & 12.00 \\
Maize offal & 14.00 & 14.00 & 14.00 & 14.00 & 14.00 \\
Rice offal & 20.05 & 20.05 & 20.05 & 20.05 & 20.05 \\
Bone ash & 3.00 & 2.25 & 1.50 & 0.75 & 0.00 \\
Pasa & 0.00 & 0.75 & 1.50 & 2.25 & 3.00 \\
Methionine & 0.20 & 0.20 & 0.20 & 0.20 & 0.20 \\
Lysine & 0.20 & 0.20 & 0.20 & 0.20 & 0.20 \\
Table Salt & 0.30 & 0.30 & 0.30 & 0.30 & 0.30 \\
Vita/min. premix & 0.25 & 0.25 & 0.25 & 0.25 & 0.25 \\
Total & 100.00 & 100.00 & 100.00 & 100.00 & 100.00 \\
Analysed Nutrient & & & & \\
(\%).Crude protein & 16.86 & 16.86 & 16.86 & 16.86 & 16.86 \\
M.E(Kcal/kg) & 2637.10 & 2637.10 & 2637.10 & 2637.10 & 2637.10 \\
\hline
\end{tabular}

Table 3. Performance of weaned rabbits fed fresh water snail (Pila Ampullacea) shell ash as a replacement for bone ash

\begin{tabular}{|c|c|c|c|c|c|c|}
\hline & \multicolumn{3}{|c|}{ Parameters } & \multicolumn{3}{|c|}{ Treatment levels } \\
\hline & $\mathrm{T}_{1}(0 \%)$ & $\begin{array}{l}\mathrm{T}_{2}(25 \% \\
\text { Pasa) }\end{array}$ & $\begin{array}{l}T_{3}(50 \% \\
\text { Pasa) }\end{array}$ & $\begin{array}{l}T_{4}(75 \% \\
\text { Pasa) } \\
\end{array}$ & $\begin{array}{l}T_{5}(100 \% \\
\text { Pasa) }\end{array}$ & SEM \\
\hline Initial weight(g) & 667.00 & 666.10 & 665.11 & 664.00 & 665.00 & \\
\hline Final weight(g) & 2237.00 & 2163.40 & 2229.60 & 2236.60 & 2236.80 & 167.11 \\
\hline ADWG & 18.70 & 17.82 & 18.61 & 18.08 & 18.68 & 1.98 \\
\hline ADFI & 85.33 & 88.33 & 90.32 & 85.14 & 84.95 & 4.68 \\
\hline $\mathrm{FE}$ & 4.56 & 4.96 & 4.85 & 4.71 & 4.55 & 0.08 \\
\hline PER & 1.06 & 0.99 & 1.06 & 1.03 & 1.07 & 0.01 \\
\hline Mortality & 0.00 & 0.00 & 0.00 & 0.00 & 0.00 & 0.00 \\
\hline
\end{tabular}

$S E M=$ Standard Error of Means; $N S=$ Not Significantly Different $(P=.05) ;$ Pasa = Pila ampullacea shell ashADWG=Average daily weight gain; $A D F I=$ Average daily feed intake, $P E R=$ Protein efficiency 
The average daily body weight gain in this finding showed no significant differences $(P>0.05)$ among the treatment groups. The ADWG of the rabbits ranged from 17.82 to $18.70 \mathrm{~g}$. This agrees with [18] who reported that oyster shell and gypsum are sources of calcium which aids metabolic activities and not principal nutrient for growth in broiler chickens. This study revealed that fresh water snail shell ash did not influence the final weight and average daily weight gain of rabbits.

The result obtained on feed efficiency did not significantly $(P>0.05)$ vary among the treatments. Feed efficiency values of 4.55 to 4.96 obtained in this study were higher than 2.63 to 4.00 reported by earlier researchers in the tropics [19]. This indicated that fresh water snail shell ash competed favourably with bone ash in terms of mineral absorption. This result also showed that the rabbits utilized their feeds for tissue synthesis.

The protein efficiency ratio range of 0.99 to 1.07 obtained in the study did not show any significant difference $(P>0.05)$ across the treatments. This indicated that fresh water snail shell ash is void of tannin which binds with protein and renders it unavailable as there was no negative effect on protein utilization. No mortality was recorded during the experimental period implying that no mineral toxicity was associated with fresh water snail shell ash.

\section{CONCLUSION}

There were no significant $(P=.05)$ differences across dietary treatments in all the performance parameters investigated. It is therefore concluded that fresh water snail shell ash can replace bone ash up to $100 \%$ without any adverse effect on the performance of weaned rabbits.

\section{RECOMMENDATION}

It was recommended that supplemental levels of Phosphorus be included in weaned rabbit's diet.

\section{DISCLAIMER}

The products used for this research are commonly and predominantly use products in our area of research and country. There is absolutely no conflict of interest between the authors and producers of the products because we do not intend to use these products as an avenue for any litigation but for the advancement of knowledge. Also, the research was not funded by the producing company rather it was funded by personal efforts of the authors

\section{ETHICAL APPROVAL}

All authors hereby declare that "Principles of laboratory animal care" (NIH publication No. 8523, revised 1985) were followed, as well as specific national laws where applicable. All experiments have been examined and approved by the appropriate ethics committee"

\section{COMPETING INTERESTS}

Authors have declared that no competing interests exist.

\section{REFERENCES}

1. FAO. (Food and Agricultural Organization). Statistical Data base. Rome, Italy. 2006;234-236.

2. British Medical Association. Basic food and nutrient requirement for Africa. In the World Book of Encyclopedia International. 1993;7:310-311.

3. Nworgu FC, Adebowale EA, Oredin OA, Oni A. Prospects and Economic of Broiler Production Using Two Plant Protein Sources. Tropical Journal of Animal Science. 1999;2(1):159 - 166.

4. Abang FBP, Attah S, Zoo E. Effect of Replacing Bone Ash with Fresh Water snail Shell Ash on Heamatological Indices of Weaner Rabbits. Annual Research and Review in Biology. 2017;21(1): 1-7.

5. Abang FB, Nwani JO, Shettima YC. Evaluation of sun-dried mango (Mangifera spp) kernel as a feed resource on the serological parameters of laying Japanese Quails. International Journal of Biochemistry Research and Review. 2018;22(3):1-7.

6. Abang FB, Ayuk AA, Okon BI. Cost effectiveness of feeding 48 hours fermented taro cocoyam meal (Colocasia esculenta var. esculenta) to growing Japanese quails (Coturnix coturnix japonica). Indian Journal of Research (Paripex). 2013;286 - 287.

7. Ajala MK, Balogun JK. Economics of rabbit production in Zaria, Kaduna State. 
TropicalJournal of Animal Science. 2004;7(1):1-10.

8. Biobaku WO, Oguntona EB. The effects of feeding multi nutrient mini blocks and pelleted diet on the growth of rabbits. Nigeria. Journal of Animal Production. 1997;24(2):147-149.

9. Omudu EA, lyough A. Ecological Studies of the Gastropod Fauna of Some Minor Tributeries of River. Research International. 2005;2(2):306-310.

10. Cobbinah JR, Vink A, Onwuka B.Snail farm: Production, Processing and Marketing. Agrodok- Series No. 47, Agromisa Foundation, CTA, Wageningen. 2008;84.

11. Saunders - Blades JL, Maclsaac JL, Korver DR, Anderson DM. The effect of calcium source and particle size on the production performance and bone quality of laying hens. Poultry Science. 2009;88:3338 - 353.

12. Wikipedia. Benue State. Geology and Environmemt. Wikipedia the freeency clopedia; 2015.

Retrieved From https://en.wikipedia. org
13. AOAC. Official Methods of Analysis of the AOAC, W. Horwitz Edition(18 ${ }^{\text {th }}$ ed) USA Washington D.C. 2006;132.

14. MINITAB Statistical Software. Minitab Inc. P.A.,US. 2014;16.

15. Obi IU. Statistical Methods of Detecting Differences Between Treatment Means. $2^{\text {nd }}$ Edition. Snaap Press. Enugu, Nigeria. 1990;25-85.

16. Pauzenga U. Feeding parent stock. Zootec. Int. 1985;22:22-24.

17. Okorie KC. The Effect of palmitic acidfortified maize wet milling by-product on the performance of weaner rabbits. Czech. Journal of Animal Science. 2003;48(9):365-370.

18. Omole AJ, Ogbosuka GE, Salaka RA, Ajayi OO. Effect of replacing oyster shell with gypsum in broiler finisher diet. Journal of Applied Sciences Research. 2005;1(2):245 - 248.

19. Ayers AC, Barrett RP, Cheeke PR. Feeding value of tree leaves (Hybrid Poplar and black locust) evaluated with sheep, goats and rabbits. Animal Feed Science Technology. 1996;57:51-52.

(c) 2021 Abang et al.; This is an Open Access article distributed under the terms of the Creative Commons Attribution License (http://creativecommons.org/licenses/by/4.0), which permits unrestricted use, distribution, and reproduction in any medium, provided the original work is properly cited.

Peer-review history:

The peer review history for this paper can be accessed here: https://www.sdiarticle5.com/review-history/74380 